\title{
PRIKAZ EMANCIPIRANE ŽENE 21. STOLJEĆA U REKLAMAMA ZA PARFEM
}

\section{Lana Gajger :: Viktorija Car}

IZVORNI ZNANSTVENI RAD / DOI: 10.20901/ms.11.22.6 / PRIMLJENO: 5.7.2020.

SAŽETAK U 21. stoljeću feministički pokret doživljava novi uzlet, a na to osobit utjecaj imaju slavne žene koje svojim djelovanjem promoviraju emancipaciju žene. Ciljovog rada bio je utvrditi kako se u reklamama za ženske parfeme prikazuje emancipiranost kao poželjna ženska osobina. Kvalitativnom istraživačkom metodom analize narativa analizirano je pet reklama za parfeme čije su glavne protagonistice slavne osobe. Njihove zajedničke karakteristike su odlučnost, s izraženim osjećajem samosvijesti, i buntovnost. One su ekstrovertirane, asertivne i sklone traženju uzbuđenja, kompetentne i orijentirane na uspjeh. Njihova poželjnost određena je istodobnim utjelovljivanjem muževnog ponašanja i estetike ženstvenosti, odbacivanjem rodnih normi (izuzev ideala vitkosti), dominantnim ponašanjem u interakciji s muškarcima te okretanjem budućnosti. Ponašanje protagonistica izrazito odgovara karakteristikama postfeminističkog poimanja ženstvenosti te podržava temeljnu odrednicu feminizma - ideju emancipacije.

\section{KLJUČNE RIJEČI}

EMANCIPACIJA, POSTFEMINIZAM, ČETVRTI VAL FEMINIZMA, SLAVNE OSOBE, REKLAMA ZA PARFEM

Bilješka o autoricama

Lana Gajger :: Fakultet političkih znanosti Sveučilišta u Zagrebu :: lanagajger@gmail.com Viktorija Car :: Sveučilište u Zagrebu, Fakultet političkih znanosti :: viktorija.car@fpzg.hr

Rad se temelji na istraživanju koje je Lana Gajger, uz mentorstvo izv. prof. dr. sc. Viktorije Car, provela za potrebe diplomskog rada "Novi obrasci u medijskim prikazima žene 21. stoljeća analiza narativa poželjnih osobina ličnosti žene u reklamama za parfem" koji je obranila na Sveučilištu u Zagrebu, na Fakultetu političkih znanosti 19. rujna 2019. godine. 


\section{UVOD: RAZVOJ EMANCIPACIJE KROZ FEMINISTIČKE VALOVE}

Način na koji je žena prikazana u medijima oduvijek je bio izravno povezan s načinom na koji je žena doživljena u društvu, ali i s načinom na koji žena doživljava samu sebe. Mediji imaju moć oblikovati koncepte poželjnosti, kreirati trendove ponašanja publike, pa i stvarati ili pak odbacivati rodne norme (Carter i Steiner, 2004; Collins, 2011, Ross i Byerly, 2004;). Upravo ta moć nerijetko se koristi u marketinške svrhe. Kapitalistička ideja da se sve može prodati primjenjuje se i na feministički pokret te njegovom komodifikacijom oglašivači ženama nerijetko prodaju sam feminizam pomno upakiran u ideju emancipacije (Gill i Scharff, 2011; Gill, 2007). Reklamna industrija u suvremenim neoliberalnim društvima eksploatira emancipiranu ženstvenost iznova koristeći ženu kao objekt, pritom iskorištavajući osobno osnaživanje žene, žensko poduzetništvo, seksualnost, pravo na zadovoljstvo i emancipaciju uopće (Lazar, 2011: 38). Prema Lazar, oglašivači pritom imaju rezigniran odnos prema komercijalnim praksama kojima ženu prikazuju lijepom (engl. beautification) u svrhu iskorištavanja ideje emancipacije žene (Ibid.: 49).

Zasluge za postojanje emancipiranih žena 21. stoljeća dakako pripadaju feminističkom pokretu, kojemu je nit vodilja oduvijek bio koncept emancipacije. On se razvijao zajedno s četiri vala feminizma od kojih je prvi započeo u 18. stoljeću i razvijao se u sljedećem stoljeću. Obilježile su ga sufražetkinje - žene koje su svoje političko pravo - pravo glasa, tražile javnim protestima (Walters, 2005: 75-85). Radikalnost koju su iskazale u prosvjedima protiv postojećega društvenog sustava i zahtijevanju vlastitih prava (razbijale su izloge, palile kuće, štrajkale glađu itd.), uvelike je odredila percepciju feminizma u očima javnosti. Stereotip o radikalnim feministkinjama koje po svaku cijenu traže svoja prava prisutan je i danas, poslije više od stotinu godina. Neupitno najveće postignuće prvog vala feminizma jest da su žene diljem svijeta dobile pravo glasa, no proces stjecanja društvene ravnopravnosti ipak je potrajao mnogo duže.

Upravo je svijest o društvenoj neravnopravnosti žene postala temeljnom okosnicom drugog vala feminizma. „Ženom se ne rađa, ženom se postaje“, povijesna je rečenica Simone de Beauvoir iz njena kultnog djela "Drugi spol" (1949., prijevod iz 2016.). Njime je de Beauvoir insinuirala nešto o čemu se do tada nije javno govorilo, a to je ideja da spol ne određuje nužno način ponašanja i cjelokupnost ličnosti. Tako su prvi put u povijesti razdvojeni pojmovi "spol“ i „rod“. "Spolom su definirane fiziološke karakteristike i anatomska razlika između muškarca i žene, dok je rodom označena društvena konstrukcija rodnih uloga" (Mihaljević, 2016: 160). Rodna jednakost postala je temeljni koncept koji čini jezgru feminističke teorije, a seksualna revolucija šezdesetih godina ženama je omogućila istraživanje, otkrivanje i eksperimentiranje s vlastitom seksualnošću te se intenzivirala rasprava o reproduktivnim pravima žene (Ibid.: 162). Usto, feministički pokret senzibilizirao je javnost na pitanje objektiviziranja ženskog tijela. Laura Mulvey u svom temeljnom eseju iz 1975. „Vizualni užitak i narativno kino" tvrdi da je sva vizualna kultura u patrijarhatu strukturirana "muškim pogledom“ (eng. male gaze) koji je sklon objektivizirati žensko tijelo i predstavljati ženu kao pasivni subjekt. Odbacivanjem tradicionalnoga patrijarhalnog društva, drugi val feminizma doveo je u centar pozornosti pitanje „Što žene žele?“. 
Razvoj trećeg vala feminizma obilježio je postmoderni duh koji podrazumijeva dekonstrukciju i preispitivanje različitih društvenih konstrukcija, uključujući i feminizam. S obzirom na to da žene nisu homogena društvena skupina, postalo je jasno da ni njihovi problemi nisu jednaki i kao takvi se ne mogu ni rješavati. Dok su se rasprave u prethodnim valovima feminizma temeljile na ostvarivanju jednakosti, treći val debatira o razlikama između samih žena, njihovim problemima i izazovima u ostvarivanju emancipiranosti. Razvija se koncept postfeminizma koji Rosalind Gill definira na tri načina: kao epistemološku promjenu, kao povijesnu transformaciju te, možda najvažnije, kao suprotstavljanje i opoziciju feminizmu (Gill, 2007: 249). Pritom je bitno istaknuti da nisu sve žene odbacile sve feminističke ideje; smatrati feminizam bespotrebnim i suvišno radikalnim, privilegija je sama po sebi, koju su najvećim dijelom uživale bijele žene zapadnjačkog društva. Za njih je nova razina emancipiranosti i odgovor na pitanje „Što žene žele?" značila imati slobodu da mogu biti kakve žele. Odbacivanjem feminizma poručile su da ih nitko - pa čak ni druga žena - nema pravo definirati.

Ipak, žene su se i dalje morale boriti za svoja prava jer seksizam kao oblik diskriminacije žena nije prestao postojati. Postfeministička autorica Naomi Wolf jednu od najvećih prijetnji emancipaciji i oslobođenju žena naziva "mitom o ljepoti“ identificirajući „sliku ženske ljepote kao političko oružje protiv ženskog napretka“ (2002: 10). Wolf govori o nedostižnim kriterijima koje ženama nameće kapitalističko društvo i marketinška industrija u svrhu profita te ih ona prepoznaje kao oblik socijalne kontrole. Te nametnute standarde ljepote žene imaju tendenciju internalizirati, a usporedba s nedostižnim standardima ljepote odvodi ih u samoprijezir, pa i samodestrukciju (Wolf, 2002). Budući da su postmodernisti rod prestali promatrati kao fiksnu odrednicu pojedinca, rasprave i težnja za ravnopravnošću postaju do jedne mjere irelevantne, a u žarište dolazi pitanje moći (ili pak nadmoći) na kojoj počiva emancipacija. Novi čin emancipacije žene Wolf vidi u prestanku postojanja „feminizma žrtvi“" i nastanku „feminizma moći“:

Žene su odjednom od kolektiva, potlačenih i ograničenih društvom, i što je najbitnije, industrijom, koji su im diktirali kako trebaju izgledati i ponašati se, prisiljavajući ih na međusobno natjecanje, postale individue, sposobne odabrati manipulirati 'mitom o ljepoti' tako da odgovara njihovim vlastitim agendama (Wolf, 1994, cit. prema Rivers, 2017: 19).

Pritom se pojam emancipacije odnosi na oslobođenje osobe ili skupine ljudi od dominacije drugog ili drugih te se temelji na diskursu o pravima (biti slobodna i sposobna za izvršavanje izbora), što je središnja ideja većine feminističkih perspektiva drugog i trećeg vala, iako je u drugom valu naglasak bio na društvenom / kolektivnom, a u trećem na osobnom / individualnom (Lazar, 2011: 49). Razumijevanje emancipacije u trećem se valu posebno uklapa u kapitalističko-potrošačke imperative koji su podvučeni individualizmom pa govorimo o potrošački orijentiranom emancipiranom identitetu žene (Ibid.).

Prema Wolf komodificirana 'ljepota' eksplicitno je povezana sa seksualnošću te je ušla „u mainstream da bi potkopala novonastali i ranjivi osjećaj ženske vrijednosti“ (2002: 11). U postfeminizmu zapravo dolazi do svojevoljnog korištenja fizičkog izgleda i seksualne subjektifikacije u promidžbene svrhe (Gill, 2007). Mnoge nekoć žestoko odbacivane rodne 
uloge, žene postfeminizma ponovno prihvaćaju i utjelovljuju s određenom dozom bezbrižnosti. Tako žena može istodobno biti intelektualka, ali i posvećena vlastitom izgledu; boriti se protiv seksizma, ali i proizvoljno se samoobjektivizirati; biti dominantna i asertivna, a istodobno ženstvena; neovisna i samodostatna, ali investirana u vlastitu privlačnost. Novu pojavu u kojoj su žene istodobno i progresivne i ženstvene Angela McRobbie (2009) naziva "novim seksualnim ugovorom".

Pojavom novih digitalnih tehnologija i društvenih medija u 2010-ima feministički aktivizam ponovno postaje aktualan te se počinje govoriti o četvrtom valu feminizma (Chamberlain, 2017; Cochrane, 2014; Rivers, 2017). Pojavljuju se feminističke blogerice, feministički forumi za globalno razmjenjivanje mišljenja, a društvene mreže Facebook, Twitter i Instagram omogućile su kampanje poput \#whyistayed/\#whyileft (s ciljem osvještavanja i prevencije nasilja u obitelji), \#YesAllWoman (kampanja protiv nasilja nad ženama), \#HeforShe (kampanja za solidarnost muškaraca sa ženama) te viralni pokret \#MeToo (osvještavanje seksualnog uznemiravanja i zlostavljanja žena). lako su i prije slavne žene utjecale na osnaživanje koncepta emancipacije (npr. u prvom je valu Coco Chanel popularizirala novi stil odijevanja - hlače i skraćenu kosu; kraljica popa Madonna 1980-ih je utjecala na razvoj tzv. porno-chica - kulture otvorenog iskazivanja ženske seksualnosti te je postala svojevrsnom začetnicom koncepta emancipirane samoobjektivizacije (više u McNair, 2002)), zbog masovnog pridruživanja slavnih i javnih osoba takvim inicijativama, govorimo o celebrity feminizmu (Rivers, 2017). Celebrity feminizam se ponajprije koristi kao estetika te se pritom nužno ne podrazumijevaju aktivni rad i borba za promjene. Samoprozvane slavne feministkinje četvrtog vala, kao što su primjerice Beyonce i Taylor Swift, posljednjih su godina inkorporirale feminizam kao relevantnu odrednicu vlastitog brenda na kojemu zarađuju milijune dolara. Pritom je Beyonce dobar primjer distinkcije između postfeminizma i četvrtog vala feminizma budući da je 2013. u intervjuu za američki časopis Vogue na pitanje smatra li se feministkinjom, odgovorila: „Ne znam. Ta riječ može biti vrlo ekstremna“ (Ellison, 2013, cit. prema Rivers, 2017: 57) da bi već godinu kasnije nastupila na MTV Video Music Awards gdje je na ekranu iza nje velikim slovima bila ispisana riječ FEMINIST. Takvo eksploatiranje feminizma možemo nazvati i postfeminističkim poduzetništvom - poslovnom strategijom umjetnica koje vještim samobrendiranjem pružaju potrošačima prostor za poistovjećivanje.

Slavne feministkinje četvrtog vala nastavljaju ono što su započele feministkinje drugog vala, a Madonna popularizirala, a to je promoviranje ideje da ženska seksualnost nije nužno ženina najveća ranjivost, već izvor moći i zadovoljstva. Pritom ostaje otvorena rasprava je li i u kojim uvjetima iskazivanje ženske seksualnosti u medijima izvor moći i zadovoljstva, a u kojoj je mjeri kriterij koji žena mora zadovoljiti da bi uopće bila relevantna publici.

Međutim, s obzirom na recentnost pojave četvrtog vala, teško je sa sigurnošću reći radi li se zaista o pojavi jednog sasvim novog vala feminizma ili novim obilježjima trećeg vala posredovanim pojavom suvremenih tehnologija. Ipak, očito je da feministički aktivizam ponovno postaje trend. 


\section{KOMODIFIKACIJA POŽELJNOSTI}

Nakon što su marketinški stručnjaci u drugom valu feminizma shvatili da reklame kojima se insinuira da je ženi mjesto u kući revoltiraju žene, počinju koristiti upravo vrijednosti za koje se feministkinje zalažu kao one koje bi se najbolje mogle prodati ženama (Geiger Zeman i Zeman, 2015: 111). Na taj se način feminizam komodificira te još za vrijeme drugog vala postaje dio mainstream oglašivačke industrije, a taj se trend nastavlja i putem postfeminističkoga poduzetništva (Vesey, 2015). Na tim idejama, u četvrtom valu feminizma nekolicina slavnih žena počinje profitirati od istog onog kapitalizma koji ih je do tada eksploatirao. Pritom, oglašivačka industrija posebno koristi koncept poželjnosti.

Poželjnost nije urođena karakterna osobina, već karakteristika koju možemo utjeloviti. U rječnicima se definira kao "kvaliteta bivanja seksualno atraktivnom“, ali i „vrijednom posjedovanja“. Sartre je još 1950-ih želju definirao kao tendenciju posjedovanja esencije "onog drugog" (Sartre, 1956: 394, cit. prema Gorton, 2008: 10). Nije stoga neobično da je komodifikacija želje, točnije poželjnosti, jedan od temeljnih izvora profita marketinške industrije. Prodaja poželjnosti kao tržišne robe, a zatim i oglašavanje određenih proizvoda kao bitnog čimbenika koji će pridonijeti individualnoj razini poželjnosti, nije usmjerena samo na žene, već i na muškarce, i to u 21. stoljeću sve učestalije. Bitna je razlika pritom „što su muškarci naučeni željeti, a žene biti poželjne“" (Gorton, 2008: 13).

Socijalizacijom je u kolektivnoj svijesti žena stoljećima oblikovan koncept ženske poželjnosti. Tradicionalno, taj je koncept podrazumijevao nježnu, brižnu, sramežljivu ženu koja je gotovo u potpunosti podređena muškarcu te je emocionalno i financijski ovisna o njemu (Ortego Roussell, 2013: 11). Generacijama su prenošene bajke u kojima su glavne antagonistice ružne, stare i zle, a ljepota djeve poistovjećena je $s$ njenom dobrotom zbog koje se na kraju udaje za princa i živi sretno do kraja života. Društveno nametnutim mitom o ljepoti, da bi se ljepota kao univerzalna kvaliteta uopće manifestirala, „žene ju moraju željeti utjeloviti, a muškarci moraju željeti posjedovati ženu koja ju utjelovljuje“ (Wolf, 2002: 18).

Danas je gotovo nemoguće pronaći reklamu ili glazbeni spot u kojem žena na ovaj ili onaj način ne ističe vlastitu seksualnost i privlačnost pri čemu je najčešće riječ o „upakiranome seksizmu koji žene priopćava prije svega kao seksualne objekte" (Mihaljević, 2016, str. 168). Žene se tako u javnom diskursu predstavljaju kao „roba“. Prema objektivizacijskoj teoriji, primarna psihološka posljedica seksualne objektivizacije je razvoj neprirodnih perspektiva na same sebe što se naziva samoobjektivizacijom (Calogero, 2004, str. 16). Žene koje se samoobjektiviziraju internalizirale su promatračevu perspektivu na svoja tijela te se kronično kontroliraju u iščekivanju kako će drugi procjenjivati njihov izgled te ih u skladu s tim i tretirati (Ibid.). Muškarci vide žene kao objekt (eng. male gaze, Mulvey, 1975), dok žene vide sebe i druge žene kroz mušku perspektivu. Na taj način, medijske slike uspostavljaju i ukorjenjuju društvena očekivanja o tome kako bi žena trebala izgledati i ponašati se, što kontinuirano pojačava njenu podređenost muškoj publici (McNair, 2002). ${ }^{1}$

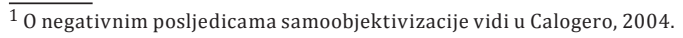


S druge pak strane, Giddens (1992) piše o seksualnosti kao još jednom mediju emancipacije i političke borbe. I prema McNairu (2002: 5) seks i kontrola nad njim bili su temelj sustava društvene podjele u kojem su stoljećima dominirali muškarci. Možda je upravo zato seksualna sloboda bitna odrednica postfeminističkog koncepta poželjnosti žene. Takva je žena jednaka muškarcima, samosvjesna te usmjerena na ispunjavanje svojih želja i istraživanje vlastite seksualnosti (Ortego Roussell, 2013: 11). Korištenjem seksualnosti u marketinške svrhe uvriježena je tvrdnja postala "seks sve prodaje“. Sklonost slavnih i utjecajnih žena seksualnom egzibicionizmu - otvorenom korištenju svoje seksualnosti i artikuliranju svoje seksualne želje kako bi privukle publiku i prodale proizvod, McNair (2002) naziva "demokratizacijom žudnje".

Ostaje nejasno, ako definicija emancipacije podrazumijeva oslobođenje žene od ovisnosti o muškarcu, a definicija poželjnosti podrazumijeva bivanje seksualno privlačnom, gdje onda samoobjektiviziranje kao aspekt postfeminističkog poduzetništva ostavlja suvremenu ženu 21. stoljeća. Čini li je uistinu oslobođenom ili se to žarište na neovisnost i samoobjektificiranje ženama danas prodaje kao "najograničeniji oblik konzumerizma i samoopredmećivanja" (Walter, 2011: 70).

\section{ODREDNICE ŽENSTVENOSTI}

U drugom valu feminizma teoriju da se muškarci i žene razlikuju po nekoliko kriterija (prve karakterizira asertivnost, agresivnost i seksualnost, a druge blagost te sklonost anksioznosti i depresiji) zamijenila je teorija da su maskulinost i femininost, odnosno muževnost i ženstvenost ${ }^{2}$ dvije dimenzije ličnosti (Buss i Larsen, 2008: 518). Drugim riječima, znanstvenici su postavili tezu da svaka pojedina osoba, neovisno o spolu, ima određenu razinu muževnosti ili ženstvenosti, a ličnost koja ima visoku razinu obje dimenzije smatrala se vrlo razvijenom i nazivala androginom (Ibid: 519). Međutim, daljnjim razvojem teorije počelo se smatrati da „ideal nije biti androgin, nego radije biti bez rodne sheme“, odnosno ne koristiti i ne povezivati spol i procesiranje socijalnih informacija (Ibid.). Upravo ono što psiholozi vide kao koncept „bez rodne sheme“, tendencija je koja se pojavila u trećem i četvrtom valu feminizma kada dolazi do otpora ikakvu obliku definiranja. Žene poprimaju određene karakteristike koje su se do tada pripisivale muškarcima, primjerice asertivnost i dominantnost.

Rodne norme su naučeni obrasci prihvatljivog i poželjnog ponašanja u skladu s rodom kojem pripadamo, a njihov produkt su rodni stereotipi (Carranza i Prentice, 2002: 269). Rodne se norme mijenjaju kroz određena vremenska razdoblja te variraju od kulture do kulture, one stvaraju rodne stereotipe, ali ponekad rodni stereotipi postanu toliko uvriježeni da utječu na oblikovanje rodnih normi (Hentschel, Heilman i Peus, 2019; McNair, 2002; Samuels i Woodhill, 2004; Stets i Burke, 2000). Unatoč konceptu koji osporava ikakvu

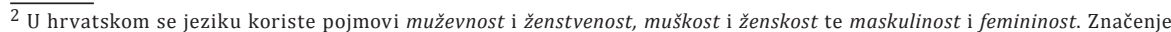
tih pojmova nije uvijek jasno te se ponekad miješaju i koriste kao istoznačnice. U literaturi iz psihologije koriste se pojmovi maskulinost i femininost (Buss i Larsen, 2008), u nekim sociološkim studijama i člancima iz područja rodnih studija autori i autorice koriste pojmove muževnost i ženstvenost (Jeknić, 2014; Geiger Zeman i Zeman, 2015; Burai, 2016), a u nekima pojmove muškost i ženskost (Galić, 2002; Janković, 2009) ili samo ženskost (Škvorc i Korljan, 2009), odnosno samo muškost (Kosanović, 2008; Maskalan, 2016). U ovom članku odlučile smo se za pojmove muževnost i ženstvenost.
} 
rodnu shemu, istraživanja rodnih stereotipa provedena na reprezentativnim uzorcima ispitanika pokazuju da se na muškarce gleda kao na „agresivne, autonomne, orijentirane na postignuće, dominantne, ekshibicioniste i ustrajne", a na žene kao "druželjubive, poslušne, heteroseksualne, brižne i samoponižavajuće" (Williams i Best, 1982; 1990, sve prema Buss i Larsen, 2008: 522).

Među odrednice ženstvenosti spadaju i osobine ličnosti koje ne smiju ostati zanemarene $u$ analizi prikaza emancipirane žene u medijskom tekstu. Prema Bussu i Larsenu „ličnost je skup psihičkih osobina i mehanizama unutar pojedinca koji su organizirani i relativno trajni te utječu na interakcije i adaptacije pojedinca na intrapsihičku, fizičku i socijalnu okolinu" (2008: 5). Prema taksonomiji koju predlaže suvremeni petofaktorski model ličnosti, temeljnih pet dimenzija ličnosti su: „ekstraverzija, ugodnost, savjesnost, emocionalna stabilnost i otvorenost", a svaku od njih karakteriziraju određene facete tendencije ponašanja koje u mjerenjima najviše koreliraju s nekom od temeljnih dimenzija ličnosti (Buss i Larsen, 2008: 510). ${ }^{3}$

Samuels i Woodhill poželjnim odrednicama ženstvenosti smatraju „suosjećanje, blagonaklonost, nježnost, osjećajnost, ekspresivnost, miroljubivost i tolerantnost", a nepoželjnim „plašljivost, blagost, pasivnost, submisivnost, skromnost, temperamentnost i krhkost“, dok se poželjnim odrednicama muževnosti smatraju "razboritost, snalažljivost, ambicioznost, nepopustljivost, praktičnost, aktivnost i hrabrost", a nepoželjnim "sebičnost, osvetoljubivost, indiferentnost, razmetljivost, sirovost, agresivnost i okrutnost" (2004: 18). McNair kao odrednice muževnosti navodi još i „kompetitivnost, racionalnost, agresivnost, pohotnost, snagu, dominantnost, predatorstvo", dok odrednicama ženstvenosti smatra „brižnost, emocionalnost, nježnost, izraženo iskazivanje ljubavi prema drugima, slabost, submisivnost, protektivnost" (McNair, 2002: 2). McNair pritom ističe da su i muževnost i ženstvenost "u značajnoj mjeri naučene, pripisane kvalitete, označene obrascima govora i ponašanja, načinom oblačenja i drugim obilježjima koji su konvencionalni, a ne biološki te se mijenjaju tijekom vremena i među kulturama" (Ibid: 3). Percipira se da poželjnost raste što je veća podudarnost između ponašanja žene i odrednica ženstvenosti te ponašanja muškarca i odrednica muževnosti (Carranza i Prentice, 2002: 272).

Odrednice ženstvenosti mogu se također podijeliti na tradicionalne i postfeminističke. Prema Ortego Roussell (2013: 11) tradicionalno poimanje ženstvenosti podrazumijeva ženu koja je slaba, podređena, ovisna o muškarcu, vitka, pretjerano emotivna, sramežljiva, pasivna, podređena, brižna majka i supruga. Tradicionalno ženstvena žena iskazuje želju za privlačenjem muškaraca te je podređena njihovim seksualnim željama. Suprotno tradicionalnom poimanju, prema postfeminističkom poimanju ženstvenosti, ženstvena je ona žena koja je usmjerena na sebe, odlučna s izraženim osjećajem samosvjesnosti, sklona krizama identiteta, njegovana, buntovna, obrazovana, neovisna, jednaka muškarcima te seksualno slobodna (Ibid.).

\footnotetext{
$\overline{3}$ Zbog zadanog opsega članka ne navodimo pojedinačne definicije (više u Buss i Larsen, 2008), iako je njihovo razumijevanje bilo nužno prilikom analize izraza lica, posture, postupaka i interakcije protagonistica s drugima u reklamama iz istraživačkog uzorka.
} 


\section{CILJ ISTRAŽIVANJA I ISTRAŽIVAČKA PITANJA}

Cilj je ovog istraživanja utvrditi kako se u reklamama za ženske parfeme prikazuje emancipiranost kao poželjna osobina žene. U žarištu su istraživanja obrasci prikaza žene u reklamama, a analiziran je prikaz emancipirane žene 21. stoljeća s pomoću rodnih normi, aspekata poželjnosti, osobina ličnosti te ponašanja protagonistice. Na početku istraživanja postavljeno je pet glavnih istraživačkih pitanja: (IP1) Kako je emancipiranost prikazana u odabranim reklamama ženskih parfema?, (IP2) Kroz koje se osobine ličnosti i kakva ponašanja protagonistica u tim reklamama oblikuje koncept ženske poželjnosti? (IP3), U kakvu su odnosu u tim reklamama emancipiranost, ženska seksualnost i postojeće rodne norme?, (IP4) Na koji se način u analiziranim reklamama upotreba parfema prikazuje kao sredstvo postizanja emancipiranosti?.

\section{METODOLOŠKI OKVIR}

Metoda istraživanja koja se koristi u ovom radu jest analiza narativa (Gillespie, 2006). Narativ je okosnica svakoga medijskog teksta, a riječ je o nizu događaja u nekom vremenu i prostoru koji su uzročno-posljedično povezani (Bordwell i Thompson, 1990: 55). Osim što prepričava događaje, narativ ih ima moć i kreirati. Metodom analize narativa možemo identificirati, opisati i objasniti strukturu, elemente i kategorije narativa u medijskim tekstovima te dobiti uvid u način na koji mediji konstruiraju sliku svijeta (više u Car i Osmančević, 2016). Kada je riječ o audiovizualnom medijskom sadržaju, analiza narativa uključuje analizu govora, zvuka, grafika (npr. pisani tekst) i slike.

U ovom istraživanju analiza narativa u odabranim reklamama zadržava se na analizi pojavnosti, izraza lica, stava, držanja protagonistica, njihovih postupaka te interakciji s drugim likovima. Istraživanje se zadržava isključivo na analizi medijskog teksta, u ovom slučaju reklame, te namjera nije bila istražiti motivaciju producentsko-kreativnih timova koji su kreirali reklame u procesima predprodukcije, produkcije i postprodukcije kao ni njihovu uvjetovanost društvenim konvencijama, niti je namjera u ovom istraživanju bila istražiti marketinške ciljeve.

\section{Uzorak}

Za ovo kvalitativno istraživanje kao namjerni uzorak odabrano je pet reklamnih spotova za ženske parfeme koji su nastali u drugom desetljeću 21. stoljeća. Protagonistice spotova redom su istaknute javne ličnosti s izrazitim globalnim utjecajem: planetarno popularne pjevačice Rihanna (višestruka dobitnica nagrade Grammy za izuzetan doprinos glazbenoj industriji) i Katy Perry (trinaest puta nominirana za Grammy), Oscarom nagrađene glumice Julia Roberts i Charlize Theron te Gigi Hadid koja je prema Forbesovoj listi za 2018. godinu među najplaćenijim modelima današnjice. Zbog njihova društvenog utjecaja i izrazite medijske prisutnosti u svijetu (milijunska publika ih prati putem društvenih mreža), ponašanje protagonistica i osobine ličnosti koje one iskazuju te aspekti privlačnosti koje one utjelovljuju bitno doprinose medijski konstruiranoj slici emancipirane žene 21. stoljeća. 
Odabrane su reklame za parfem budući da kad govorimo o poželjnosti, teško je pronaći proizvod čija je svrha jednoznačnija od parfema. Prema definiciji nastaloj sredinom 20. stoljeća „temeljna svrha parfema je učiniti žene atraktivnijima i privlačnijima“ (Verrill, 1940: 91, 97, cit. prema Classen, Howes i Synnott, 1994: 162). Miris je, sam po sebi, vrlo teško dočarati riječima, stoga se marketing parfema fokusira na evociranje fantazija, a percepcija parfema se ne sastoji samo od senzacija njegova mirisa već i od iskustava i emocija povezanih s njima (npr. misterioznost, seksualna poželjnost, i sl.). Trend celebrity parfema nastao je 2000-ih, u vrijeme kad je pop-glazba doživjela ponovni porast popularnosti, a predvodnice razvoja te vrste poduzetništva bile su Britney Spears i Jennifer Lopez (Vesey, 2015). U duhu postfeminističkog poduzetništva, izleti poznatih i slavnih osoba u kozmetičku i modnu industriju postali su uobičajeni, osobito u vrijeme kada ne rade na nekom projektu (novom albumu, filmu i sl.), kako bi povećale svoju povezanost s obožavateljima i utvrdile poziciju na tržištu.

Riječ je o reklamama za (1) Diorov parfem „J'Adore“ sa Charlize Theron u glavnoj ulozi (2014., r. Jean-Baptiste Mondino), ${ }^{4}$ bočica je potpuno zlatna; (2) "Killer queen“ - parfem koji promovira Katy Perry (2013., r. Jonas Akerlund), ${ }^{5}$ a bočica je u obliku dragulja smještenog na vrhu kraljevskog žezla; (3) Rihannin parfem „Reb'l fleur" (2011., r. Dave Meyers), 6 bočica parfema u obliku je štikle; (4) parfem Tommyja Hilfigera „The Girl“ s Gigi Hadid u glavnoj ulozi (2016., r. Mikael Jansson), ${ }^{7}$ na bočici je simbol sidra; (5) Lancômov parfem "La vie est belle" s Julijom Roberts u glavnoj ulozi (2016., r. James Gray), ${ }^{8}$ u bočici sa sivom mašnicom, a presjek bočice je u obliku lađe.

\section{ANALIZA}

\section{Emancipacija žene: od objektiviziranog objekta do samoobjektiviziranog subjekta}

\section{J'Adore}

U dvorcu Versailles, rezidenciji francuskih vladara i mjestu gdje je nastao dvorski apsolutizam, osobito je povijesno značajna Dvorana zrcala. ${ }^{9} \mathrm{U}$ prostoriju u kojoj su se kroz povijest sastajali najmoćniji muškarci svijeta i donosili važne političke odluke koje su utjecale na sudbine milijuna ljudi, suvereno i odlučno ušetala je jedna žena - protagonistica reklame za parfem "J'adore"10 - Charlize Theron. Njeno prisustvo najavljeno je zvukom visokih potpetica - karakterističnog simbola ženstvenosti. Prije nego se počne uspinjati „prema gore" po svilenoj tkanini, koja se poput užeta za spašavanje spušta kroz središte otvorene kupole, Charlize odbacuje crnu tkaninu koja joj je do tada pokrivala ramena i leđa. Na svetim mjestima diljem svijeta još se uvijek, prema religijskim normama, pristojnim smatra pokriti tijelo odjećom, stoga taj element narativa ima utoliko snažnije značenje ako u obzir

\footnotetext{
$\overline{4}$ https://www.youtube.com/watch?v=yZ1XM9LwS64 (07.04.2020.)

5 https://www.youtube.com/watch?v=n7epC8ZW92Y (07.04.2020.)

${ }^{6}$ https://www.youtube.com/watch?v=iyy4wn3E730 (07.04.2020.)

${ }^{7}$ https://www.youtube.com/watch?v=TSBGN9VaiMA (07.04.2020.)

${ }^{8}$ https://www.youtube.com/watch?v=RrrC-YDnVzU (07.04.2020.)

${ }^{9} \mathrm{U}$ njoj su 1919 . godine potpisani mirovni ugovori kojima je završio Prvi svjetski rat.

10 franc. obožavam
} 
uzmemo činjenicu da su žene stoljećima bile potlačene upravo zbog svoje seksualnosti. Charlize izuva visoke potpetice (također nešto što je rodnim normama namijenjeno samo ženama) te se bosonoga kao akrobatkinja počinje penjati po svili prema otvoru kupole (veranje po, primjerice, drveću je nešto što prema rodnim normama nije dolikovalo ženama, tj. djevojčicama (Koch, 2003: 266). Potom trga bisernu ogrlicu koja joj je toliko gusto nanizana oko vrata da simbolički podsjeća na lanac ili uteg.

Kupola kroz koju Charlize prolazi u „novi svijet“ zapravo ne postoji u originalnom tlocrtu Dvorane zrcala. Kupola je karakteristična za crkvene građevine; smještena je na križištu brodova, točno iznad oltara, te je mjesto kroz koje svjetlost ulazi u crkvu. Možemo zaključiti da je „prema gore“ svojevrstan put prema nečem uzvišenom, božanskom. Tom dojmu doprinosi i snažna svjetlost koja dopire kroz otvor, kao i činjenica da je vrh kupole oslikan tako da predstavlja nebo i oblake. „Jedini izlaz je prema gore“, kaže Charlize dok se penje i kroz otvor izlazi na krov kupole odakle se pruža pogled na pomalo futuristički grad prepun osvijetljenih nebodera.

Charlize je prikazana kao žena koja predvodi u budućnost i otkriva novi svijet, što je uloga (a samim time i rodna norma) koja je tijekom povijesti pripadala isključivo muškarcima. Usto, penjanjem i prolaskom kroz svjetlo na svodu anđelima i oblacima oslikane kupole, Charlize je žena koja ne samo da vodi u novi svijet, već i doseže božansko, iako je stroga rodna norma u religijama diljem svijeta ta da su posrednici između Boga i naroda uvijek muškarci. Njezin prolazak kroz svod kupole također aludira i na poznati koncept „staklenog stropa“ koji označava niz nevidljivih prepreka koje ženama onemogućuju napredovanje na više poslovne pozicije.

Dok korača po krovu kupole, Charlize objašnjava: „To nije raj. To je novi svijet. Budućnost je zlato. J'adore". Reklama poručuje da ne treba živjeti u prošlosti, trebamo se osloboditi njenih okova i popeti se u blistavu budućnost. A u tu budućnost suvereno nas vodi jedna emancipirana žena i, dakako, parfem francuske kuće Dior.

\section{Killer Queen}

Status Versaillesa kao povijesnog simbola apsolutističke moći muškaraca iskorišten je i u reklami za parfem Katy Perry "Killer Queen“. Katy je stilizirana kao dvorska dama: lice joj je napudrano bijelim puderom, na usnama je crveni ruž, a na glavi bijela napudrana perika. Obuvena je u crne čizme s vrlo visokim, tankim potpeticama, a odjevena je u zategnuti korzet i crvenu haljinu. Utjelovljuje notornu francusku kraljicu Mariju Antoanetu, na što nas upućuju i stihovi pjesme Killer Queen, rock-grupe Queen. Jedino poznatije od njezine navodne izjave „ako nemaju kruha, nek' jedu kolače“ jest činjenica da su njezina rastrošnost i krajnje nepoštivanje konvencija tadašnjega francuskog društva bili okidač za početak Francuske revolucije, pobune potlačenih i izrabljivanih Francuza, koja je rezultirala ukidanjem staleža i robovlasničkih odnosa nad ženama i manjinama, te prestankom postojanja Francuske kao apsolutističke monarhije.

Preokret se događa kada Katy odguruje dvorane oko sebe, nožem prereže svoju haljinu, odbacuje ju i ostaje u korzetu i kratkoj haljini koja joj otkriva noge. Katy odbacuje 
rubine oko vrata, a s glave zbacuje tešku periku i raspušta svoju dugu, valovitu, crnu kosu. Potom uzima parfem, nanosi ga zadovoljno se smiješeći, a zatim tu istu bočicu parfema vidimo kao vrh kraljevskog žezla koje Katy dohvati prije nego što izađe iz prostorije. Katy trči, izazivajući zgražanje prisutnih muškaraca, ruši nogom kraljevsko postolje, sjeda na njega, a na glavu nakrivljeno postavlja krunu optočenu rubinima. Pobjedonosno izgovara "Own the throne!"

Katy u reklami prikazuje dvije potpuno suprotne ličnosti - damu francuskog dvora koja u potpunosti podliježe konvencijama društva, a zatim oslobođenu ženu 21. stoljeća koja, uz pomoć parfema, odbacuje sve norme i preuzima kraljevski tron. Pri analizi njena ponašanja zanimljivo je uočiti da prije trenutka u kojem se pobunila protiv procesa uljepšavanja i nametnutih konvencija, ona iskazuje nepoželjne odrednice ženstvenosti kao što su pasivnost, submisivnost, slabost i krhkost (Samuels i Woodhill, 2004: 18). Međutim, nakon pobune umjesto poželjnih odrednica ženstvenosti (suosjećanje, blagonaklonost, nježnost, osjećajnost, ekspresivnost, miroljubivost i tolerantnost), ona počinje iskazivati poželjne odrednice muževnosti: ambicioznost, nepopustljivost, aktivnost, hrabrost i snagu (Ibid.). Prije pobune Katy iskazuje brojne tradicionalne odrednice ženstvenosti (slaba, podređena, pasivna te vitka, atraktivna i seksualno privlačna), a nakon pobune gotovo u potpunosti iskazuje postfeminističke odrednice ženstvenosti (odlučna s izraženim osjećajem samosvjesnosti, prolazi kroz krizu identiteta, buntovna je, neovisna i samostalna).

\section{Reb'l fleur}

Još jedna reklama čija protagonistica iskazuje vidnu promjenu karaktera jest ona za Rihannin parfem „Reb'l fleur". ${ }^{11}$ U njoj Rihanna ne samo da izaziva uvriježene koncepte prihvatljivog i neprihvatljivog ponašanja žena nego se i na zanimljiv način poigrava idejom o tome što žene smatraju poželjnim i nepoželjnim. Na početku reklame Rihanna je nježna djevojka, odjevena u ružičasto i smještena u perje. Bijegom od muškaraca kroz labirint vrta prolazi kroz zrcalo, a boja odjeće mijenja joj se u crnu. Prestaje bježati te svjesno počinje privlačiti pozornost muškaraca koji joj ne mogu odoljeti. U svijetu iza zrcala "ono loše", zabranjeno, zapravo je dopušteno i slavljeno. To zaključujemo i iz natpisa na zrcalu "Good feels so bad" / "Bad feels so good".

Prolaskom kroz zrcalo Rihannino se ponašanje mijenja. Ona prestaje biti plijen te preuzima kontrolu nad situacijom - postaje predator. Svjesna muškaraca koje privlači ona samosvjesno i bez straha šeće vrtom. Ulaženjem u seksualnu interakciju s tri muškarca, Rihanna dotiče i tabue vezane uz ženske seksualne fantazije o kojima se ni u najliberalnijem zapadnjačkom društvu ne govori javno. Da bi se prepustila svojim seksualnim željama, Rihanna je morala prijeći u alternativni svemir, morala je postati „zločesta“. Na vrhuncu te interakcije, što je i vrhunac reklame, ona izvlači bočicu parfema, čime se implicira povezanost parfema s ispunjenjem želja i fantazija.

Međutim, nakon što ih je Rihanna ostvarila, vrijeme i se događaji počinju vraćati unatrag i ona se povratkom kroz zrcalo vraća u prvobitnu nježnost u ružičastoj haljini - nevina

\footnotetext{
$\overline{{ }^{11} \text { Naziv }}$ parfema dolazi od francuskih riječi rebelle fleur, što u doslovnom prijevodu znači cvijet pobunjenik, što je bio Rihannin nadimak koji joj je u djetinjstvu nadjenula baka.
} 
i društveno prihvaćena. Ostaje nejasna ta dvostrana poruka. S jedne strane ženama se poručuje kako upravo uz taj parfem mogu ispuniti sve svoje potisnute želje i pritom izbjeći najveći strah, kojim se stoljećima održava postojanje rodnih normi - društvenu osudu, ali s druge strane, povratkom u prvobitnu nevinost, šalje se kontradiktorna poruka da nije u redu biti i ostati slobodoumna te ispuniti potisnute želje. Zapravo se poručuje da izlet u fantaziju u kojoj žena ne mora uvažavati konvencije, u kojoj odbacuje rodne norme i u kojoj je emancipirana, mora ostati upravo to - samo izlet.

Analiza narativa pokazuje da "dobra Rihanna“, prije prolaska kroz zrcalo, utjelovljuje sve ono što se smatra tradicionalnim odrednicama ženstvenosti (slaba, pasivna, podređena, nježna, vitka i atraktivna), a „loša Rihanna“, ona nakon prolaska kroz zrcalo, prikaz je postfeminističke ženstvenosti (otkriva vlastitu seksualnost, odlučna je i s izraženim osjećajem samosvjesnosti, seksualno je slobodna te inicira odnos s većim brojem partnera, buntovna je, prolazi kroz krizu identiteta). Freud je tvrdio da jedan dio uma stvara ljudske porive, „drugi dio ima osjećaj o tome što civilizirano društvo očekuje, a treći pokušava zadovoljiti porive unutar okvira realnosti i društva" (Buss i Larsen, 2008: 277). Rihannin parfem svojevrsno je obećanje o seksualnoj slobodi i ispunjenju zabranjenih želja.

\section{The Girl}

Reklama za parfem Tommyja Hilfigera „The Girl“ također se poigrava idejom seksualno dominantne žene. U pokušaju kategorizacije mirisa Classen, Howes i Synnott (1994: 162) navode da su "zavodnice fatalne žene, sirene koje mame ljude na smrt" te da "simboliziraju opasnu atraktivnost". U ovoj reklami Gigi Hadid je utjelovila stereotip fatalne zavodnice. Izrazito vitka, visoka, dugonoga plavuša, plavih očiju i pripadnica bijele rase Gigi je protagonistica s kojom se rijetko koja žena može identificirati, ali zato mnoge čeznu za njezinom pojavnošću, što je čini izvrsnim subjektom kapitalističke komodifikacije.

Gigi se njiše na velikom sidru koje visi s broda, odjevena u kapetansku odoru, a ispod nje su mornari koji je prate pogledima. Kad ona prošeće kraj mornara, nitko ne ostaje ravnodušan, a jedini od njih kojemu je odabrala prići - završio je u moru. Ona pobjeđuje i u igri obaranja ruke. Muškarci hipnotizirano prate svaki njen pokret, a ona suvereno vlada njihovom pozornošću. Njihanjem na sidru, zbog kojeg mornari moraju podići pogled kako bi u nju gledali, ali i kapetanskom uniformom u koju je odjevena, slikovito se dočarava da je ona iznad njih, da im je nadređena. Svjesnim usmjeravanjem pozornosti muškaraca u skladu s vlastitim željama Gigi kontrolira njihovu interakciju, što je stavlja u vrlo osnaženu poziciju - na taj način ona od objekta postaje subjekt.

U duhu postfeminizma Gigin izražen osjećaj samosvjesnosti, seksualna sloboda i iniciranje seksualne interakcije, njena neovisnost i nadmoćnost nad muškarcima razlozi su zbog kojih je se ne može smatrati žrtvom seksualne objektivizacije muškaraca. Stihovima "I follow you“ dodatno se pojačava poruka da su takvu ženu muškarci spremni slijediti, a i sam naziv parfema koji uključuje određeni član the - „The Girl“ označava jedinstvenost i posebnost takve žene. 


\section{La vie est belle}

Već na samom početku reklame za Diorov parfem „La vie est belle"12 odbacivanje normi najavljuje se riječima: „U svijetu prepunom diktata i konvencija, postoji li drugi način?" Julia Roberts na glamuroznoj zabavi u Parizu u dugoj, bijeloj haljini odskače od svih drugih gostiju koji su odjeveni u crno. Izborom bijele boje upućuje na to da ona nije podređena uobičajenim normama društva. Julia je inače jedina od protagonistica analiziranih reklama koja nije prikazana kao zavodnica. Prijeloman trenutak u narativu te reklame događa se kad Julia promatranjem odraza u zrcalu shvati da su ona i svi oko nje poput marioneta kontrolirani tankim srebrnim nitima koje su im obavijene oko zglobova te im „diktiraju“ ponašanje. Ona se svojih s lakoćom oslobađa te se uspinje stepenicama prema blistavim svjetlima. Na vrhu se okrene sa širokim osmijehom na licu i izjavljuje „La vie est belle". U krupnom je kadru bočica parfema obavijena nitima koje pucaju kako se bočica vrti te se pritom i svi ostali oslobađaju tih niti koje su ih vezivale. Baš kao i Charlize, Julia je također žena koja nas predvodi u neki novi svijet - svijet u kojem smo oslobođeni društvenih ideja o tome tko bismo trebali biti i kako bismo se trebali ponašati, svijet u kojem je život utoliko ljepši.

\section{RASPRAVA}

U analizi pet izabranih reklama uočeno je pet kategorija narativa koje možemo povezati s postfeminizmom i četvrtim valom feminizma: (1) istodobno utjelovljivanje muževnog ponašanja i estetike ženstvenosti; (2) odbacivanje normi i predvođenje u novu budućnost; (3) transformacija ličnosti i ponašanja iz tradicionalnih u postfeminističke odrednice ženstvenosti; (4) dominantno ponašanje žena u interakciji s muškarcima; (5) utjelovljivanje koncepta emancipiranosti uz komodificiranje seksualne subjektifikacije.

(1) Prema Bussu i Larsenu (2008) maskulino ponašanje karakterizira „asertivnost, smjelost, dominacija i samodostatnost", a upravo se tako ponašaju sve analizirane protagonistice, izuzev Rihanne i Katy Perry prije prijelomnog trenutka „transformacije ličnosti“ (kad jedna prolaskom kroz zrcalo postaje loša djevojka, a druga odbacuje konvencije dvora i postaje kraljica). Takvo ponašanje odgovara onome što se smatra postfeminističkom ženstvenošću. Bez obzira na maskulino ponašanje, sve protagonistice utjelovljuju ideal vitkosti te vrlo femininu estetiku - one haljinama, visokim potpeticama, šminkom i frizurama naglašavaju svoju ženstvenost. To utjelovljivanje naizgled kontradiktornih karakteristika, kao što su muževno ponašanje i estetika ženstvenosti, uvriježeno je za postfeminizam i četvrti val feminizma.

(2) Odbacivanje normi i predvođenje u novu budućnost uočavamo u svim analiziranim reklamama. Svaka protagonistica na svoj je način odbacila rodne norme: Charlize i Julia pokazuju da su žene, a ne muškarci, one koje otkrivaju i predvode u novi i bolji svijet, Katy je odbacila sve konvencije patrijarhalnog francuskog dvora, a Rihanna prolaskom kroz zrcalo istražuje neki novi svijet u kojem odbacuje ulogu submisivne žene i uživa u svojoj seksualnoj nadmoći nad muškarcima. Prikaz nadmoći nad muškarcima, tj. odbaci-

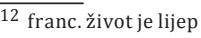


vanje ideje ženske submisivnosti, prisutan je i kad Gigi pobjeđuje muškarce u odmjeravanju snaga. Gigi je kapetanica broda i predvodnica posade te žena na poziciji koja prema rodnim normama pripada muškarcu.

(3) Transformaciju ličnosti i ponašanja iz tradicionalnih odrednica ženstvenosti u postfeminističke vrlo slikovito utjelovljuje Rihanna. Ona od slabe, sramežljive, pasivne žene, koja iskazuje želju za privlačenjem pažnje muškaraca, prolaskom kroz zrcalo postaje odlučna, izrazito samosvjesna verzija sebe, koja istražuje svoju seksualnost i uživa u svojoj seksualnoj slobodi, a zatim se vraća kroz vrijeme te prolaskom kroz zrcalo ponovno utjelovljuje tradicionalne odrednice ženstvenosti. Katy Perry također, u duhu postfeminističkih odrednica ženstvenosti, proživljava svojevrsnu krizu identiteta u trenutku kad odbacuje ulogu pasivne dvorske dame te postaje buntovna kraljica koja uspinjanjem na tron iskazuje svoju nadmoćnost. Dok su transformacije kroz koje prolaze Rihanna i Katy Perry očigledno i slikovito prikazane, Charlize Theron i Julia Roberts također proživljavaju transformacije, ali su one nešto suptilnije prikazane. Zajednički im je koncept „uspinjanja”. Katy Perry i Charlize Theron odbacuju dijelove nakita i odjeće koji simboliziraju prošlost, a zatim se jedna uspinje na tron, a druga na kupolu. U trenutku kad odbaci cipele i ogrlicu kao simbole tradicionalne ženstvenosti, Charlize preuzima ulogu vođe te nas odlučno i samosvjesno predvodi u novi svijet - penjući se na vrh kupole. U trenutku kad odbaci okove društvenih konvencija, Julia prestaje biti pasivna marioneta i uspinjanjem po stepenicama također se nameće kao vođa.

(4) Sve protagonistice, osim Julije Roberts, prikazane su neravnopravnima, već dominantnima u odnosu na muškarce. Gigi se njihala na sidru, zbog čega su mornari morali podizati pogled kako bi je vidjeli, gurnula je jednog od njih u more, a drugog pobijedila u odmjeravanju snaga i općenito je upravljala interakcijom s mornarima. Rihanna je nakon prolaska kroz zrcalo od plijena postala predatorica, a Katy Perry je naočigled zgroženih muškaraca na dvoru prošetala pred njima u kratkoj haljini, namignula im i preuzela tron. Charlize nije prikazana u interakciji s muškarcem, ali je simbolički preuzela cijeli Versailles, centar apsolutističke moći muških vladara.

(5) Sve analizirane protagonistice utjelovljuju koncept emancipiranosti. One su oslobođene od svih oblika ovisnosti o muškarcu, autonomne i mijenjaju društvene prilike i osobne životne uvjete te su seksualno slobodne. Gigi kao kapetanica broda predvodi svoju posadu i u svakom je aspektu dominantna i autonomna figura među brojnim muškarcima, Charlize i Julia nas predvode u novi svijet odbačenih normi, Katy preuzima tron, a Rihanna (nakon prolaska kroz zrcalo) doseže i promovira seksualnu slobodu, tj. odbacivanje seksualnih tabua.

Činjenica je da sve protagonistice analiziranih reklama odbacuju rodne norme čime promoviraju emancipiranost. Kontradiktorno tome, tjelesni izgled svih protagonistica u skladu je s normama privlačnosti i poželjnosti. Možemo zaključiti da je u analiziranim reklamama koncept emancipiranosti nejasno definiran u kontekstu komodifikacije ženskog tijela i izrabljivanju fizičke privlačnosti žene kao prvog i najrelevantnijeg aspekta poželjnosti. lako protagonistice odbacuju mnoge rodne norme, i dalje su čvrsto vezane uz one 
koje se odnose na fizički izgled, a koje ih čini privlačnima. Stoga zaključujemo da "mit o ljepoti“ (Wolf, 2002) opstaje i u četvrtom valu feminizma iako pritom žena nije prikazana kao objekt, već kao subjekt.

\section{ZAKLJUČAK}

Koncept postfeminističkog poduzetništva kao biznis-modela omogućuje afirmiranim javnim ličnostima da zarađuju na vlastitoj poželjnosti na način da svoju ličnost i pojavu komodificiraju u određeni proizvod. Kad se ženama, koje su već same po sebi svojim postignućima, društvenim statusom i izgledom utjelovljenje poželjnosti, omogući globalna medijska platforma, onda njihovo ponašanje, preferencije i ideje koje zastupaju utječu na trendove ponašanja i razmišljanja publike te oblikuju koncepte poželjnosti. Karakteristike koje se $u$ analiziranim reklamama percipiraju poželjnima su istodobno utjelovljivanje muževnog ponašanja i estetike ženstvenosti, odbacivanje rodnih normi (izuzev onih koje doprinose fizičkoj privlačnosti), dominantno ponašanje žena u interakciji s muškarcima te okretanje budućnosti koju predvodi emancipirana žena. Na taj način ne samo da protagonistice analiziranih reklama propagiraju koncept emancipiranosti već istodobno i definiraju njegovo značenje za ženu 21. stoljeća.

Ideja emancipacije $u$ analiziranim reklamama prikazana je kao poželjna karakteristika žene 21. stoljeća (IP1). Emancipiranost je istodobno prikazana kao jedna od temeljnih karakteristika koje analizirane protagonistice čine privlačnima, ostvarenima i zadovoljnima životom. Također, emancipiranost se prikazuje kao ono čemu bi žene trebale težiti, a mogu utjeloviti korištenjem parfema.

U analiziranim reklamama koncept ženske poželjnosti karakteriziraju estetika ženstvenosti koja podrazumijeva naglašavanje ženstvenosti isticanjem atributa i muževno ponašanje koje podrazumijeva asertivnost, smjelost, dominaciju i samodostatnost (IP2). Osobine ličnosti koje se pritom prikazuju poželjnima su ekstraverzija (facete asertivnost i sklonost traženju uzbuđenja), savjesnost (facete kompetentnost i orijentiranost na uspjeh) i otvorenost (sve protagonistice sklone su liberalnim vrijednostima). Poželjnost se utjelovljuje u liku tjelesno privlačnih, vitkih i ženstvenih žena, koje svoju privlačnost naglašavaju u skladu s rodnim normama. U tri reklame eksplicitno se prikazuju odbacivanje nepoželjnih i tradicionalnih odrednica ženstvenosti te prihvaćanje postfeminističkih odrednica ženstvenosti, kao i iskazivanje poželjnih odrednica muževnosti (Katy Perry, Rihanna, Julia Roberts), a u preostale dvije implicira se poželjnost takvih karakteristika prikazivanjem protagonistice (Gigi Hadid i Charlize Theron) koja već utjelovljuje poželjne odrednice muževnosti i postfeminističke odrednice ženstvenosti.

Sve protagonistice utjelovljuju rodne norme koje se odnose na tjelesnu privlačnost, dok istodobno prikazuju odbacivanje svih drugih normi kao čin emancipacije (IP3). U reklamama u kojima su došle u interakciju s muškarcima možemo vidjeti da je upravo seksualnost protagonistica (točnije njihovo seksualno subjektificiranje) izvor njihove nadmoći nad muškarcima. One se odabiru prikazati poželjnima i svjesno se stavljaju u centar po- 
zornosti, zbog čega od objekta postaju subjekt, stoga ne možemo više govoriti o tome da ih muškarci objektificiraju - što se smatra jednim od povijesnih uzroka potlačenosti žena. One sada imaju slobodnu volju, mogućnost odabira i kontrolu nad svojim životom, što ih čini emancipiranima. Preostaje pitanje je li samoobjektifikacija i pozicija subjekta u kojoj i dalje nastoje biti privlačne muškarcima uistinu emancipiranost ili samo lažni osjećaj nadmoći.

U analiziranim reklamama sugerira se povezanost između korištenja parfema i odbacivanja rodnih normi (IP4). Parfem simbolički predstavlja esenciju emancipiranih protagonistica, a čin nanošenja parfema poistovjećuje se s emancipiranošću. Na taj se način ideja emancipacije žene 21. stoljeća koristi u marketinške svrhe. Nameću se pritom pitanja tko i s kojim marketinškim namjerama konstruira takve narative te jesu li oni svjestan izbor i odluka protagonistica koje su ih utjelovile. Bez tih informacija te bez istraživanja utjecaja koje analizirane reklame imaju na publiku nije moguće procijeniti utječu li, u kojoj mjeri i na koje načine, takvi narativi na emancipaciju žene 21. stoljeća; potraga za tim odgovorima ipak izlazi iz okvira ovog istraživanja. lako smo svjesne ograničenja takve vrste istraživanja, želja nam je bila potaknuti razgovor o razumijevanju medijske konstrukcije emancipiranosti žene.

Kao što su postfeminizam i četvrti val feminizma često kontradiktorni, takvom je, u analiziranim reklamama, prikazana i suvremena žena 21. stoljeća. Ona istodobno utjelovljuje estetiku ženstvenosti i muževno ponašanje. Ona promovira emancipiranost, ali prihvaća rodne norme koje ju čine privlačnom muškarcima. Njena osobnost nije ni isključivo muževna ni isključivo ženstvena, ali nije ni androgina jer odlazi iz jedne krajnosti u drugu. Možda baš iz te kontradikcije prikaz emancipirane žene 21. stoljeća polako stiže do ideala „bez rodne sheme“. Ona više nije slaba, nježna i krhka dama koju treba spasiti, već fatalna zavodnica koja zna što želi od života i vrlo je kompetentna to i ostvariti. Ona je odlučna, samosvjesna, dominantna, seksualno nesputana i iako je vrlo, vrlo seksi, ona nije seksualni objekt, već seksualni subjekt.

I na kraju, ne možemo se ne zapitati kako žena može istodobno utjeloviti toliko naizgled proturječnih karakteristika. Odgovor, iako banalan, uistinu jest „zato jer može“ i upravo je to postignuće i ultimativna težnja feminizma: žena slobodna biti tko god i što god želi. Tražeći jednakost i ravnopravnost, žena se bori za emancipaciju - koja očito ponekad podrazumijeva i izbor samoobjektiviziranog subjekta.

\section{Literatura}

>Bordwell, David i Thompson, Kristin (1990) Film Art: An Introduction. New York: McGraw-Hill. $>$ Burai, Renata (2016) Sukonstrukcija interkulturalnog kurikuluma. Komparacija određenih obilježja hrvatske kulture kod srednjoškolaca i njihovih nastavnika (Hofstedeov model). Školski vjesnik 65 (2): 181-208.

>Buss, David i Larsen, Randy (2008) Psihologija ličnosti. Jastrebarsko: Naklada Slap. >Calogero, Rachel M. (2004) A Test of Objectification Theory: The Effect of The Male Gaze on Appearance Concerns in College Women. Psychology of Women Quarterly 28 (1): 16-21. DOI: 10.1111/j.1471-6402.2004.00118.x 
>Car, Viktorija i Osmančević, Leali (2016) Televizijski narativi - pričam ti priču. Sarajevski žurnal za društvena pitanja 5 (1-2): 7-27.

$>$ Carranza, Erica i Prentice, Deborah A. (2002) What Women and Men Should Be, Shouldn't be, are Allowed to be, and don't Have to Be: The Contents of Prescriptive Gender Stereotypes. Psychology of Women Quarterly 26 (1): 269-281. DOI: 10.1111/1471-6402.t01-1-00066

$>$ Carter, Cynthia i Steiner, Linda (2004) Critical Readings: Media and Gender. Maidenhead: Open University Press.

>Chamberlain, Prudence (2017) The Feminist Fourth Wave: Affective Temporality. London:

Palgrave Macmillan.

>Classen, Constan, Howes, David i Synnott, Anthony (1994) Aroma: The Cultural History of Smell. London: Routledge.

>Cochrane, Kira (2014) All the Rebel Women: The Rise of the Fourth Wave Feminism. London:

Simon \& Schuster.

$>$ Collins, Rebecca L. (2011) Content Analysis of Gender Roles in Media: Where Are We Now and Where Should We Go? Sex Roles 2011 (64): 290-298. DOI: 10.1007/s11199-010-9929-5

$>$ de Beauvoir, Simone (2016) Drugi spol. Zagreb: Naklada Ljevak.

$>$ Galić, Branka (2002) Moć i rod. Revija za sociologiju 33 (3-4): 225-238.

$>$ Geiger Zeman, Marija i Zeman, Zdenko (2015) Potrošački snovi chic djevojaka: rodno lice konzumerizma. Narodna umjetnost 52 (2): 105-137. DOI: 10.15176/vol52no206

$>$ Giddens, Anthony (1992) The Transformation of Intimacy: Sexuality, Love and Eroticism in Modern Societies. Stanford: Stanford University Press.

$>$ Gill, Rosalind (2007) Gender and the Media. Cambridge: Polity.

>Gill, Rosalind i Scharff, Christina (2011) New Femininities: Postfeminism, Neoliberalism and

Subjectivity. New York: Palgrave Macmillan.

>Gillespie, Marie (2006) Narrative Analysis, str. 79-117 u Gillespie, Marie i Toynbee, Jason (ur.)

Analysing Media Texts. New York: Open University Press.

$>$ Gorton, Kristyn (2008) Theorizing Desire: From Freud to Feminism to Film. New York: Palgrave Macmillan.

$>$ Hentschel, Tanja, Heilman, Madeline E. i Peus, Claudia V. (2019) The Multiple Dimensions of Gender Stereotypes: A Current Look at Men's and Women's Characterizations of Others and Themselves.

Frontiers in Psychology 10 (11): 1-19. DOI: 10.3389/fpsyg.2019.00011

>Janković, Vesna (2009) Cyberfeminizam između teorije i pokreta. Osvrt na Hrvatsku. Socijalna ekologija 18 (1): 5-27.

>Jeknić, Ranka (2014) Rodna ravnopravnost, mlade žene i kultura u kontekstu „muževnosti/ ženstvenosti" kao dimenzije modela "nacionalne kulture" Geerta Hofstedea. Zbornik radova Pravnog fakulteta u Splitu 51 (3): 681-696.

>Koch, Janice (2003) Gender Issues in the Classroom, str. 259-281 u Reynolds, William M. i Miller, Gloria E. (ur.) Handbook of Psychology. New Jersey: John Wiley \& Sons.

$>$ Kosanović, Silvana (2008) Suvremene muško-ženske konstrukcije u američkim televizijskim serijama Seks i grad, Kućanice i Vatreni dečki. Medijska istraživanja 14 (2): 87-102.

>Lazar, Michelle M. (2011) The Right to be Beautiful: Postfeminist Identity and Consumer Beauty

Advertising, str. 37-51 u Gill, Rosalind i Scharff, Christina (ur.) New Femininities: Postfeminism, Neoliberalism and Subjectivity. New York: Palgrave Macmillan.

>Maskalan, Ana (2016) U ime oca: rasprava o (novom) očinstvu, njegovim pretpostavkama i preprekama. Revija za socijalnu politiku 23 (3): 383-398.

$>$ McNair, Brian (2002) Striptease Culture: Sex, Media and the Democratization of Desire. London: Psychology Press.

>McRobbie, Angela (2009) The Aftermath of Feminism. Gender, Culture, and Social Change. London: Sage.

>Mihaljević, Damirka (2016) Feminizam - što je ostvario? Mostariensia 20 (1-2): 149-169.

$>$ Mulvey, Laura (1975) Visual Pleasure and Narrative Cinema. Screen 16 (3): 6-18. DOI:10.1093/

screen/16.3.6 
IZVORNI ZNANSTVENI RAD / DOI: 10.20901/ms.11.22.6 / PRIMLJENO: 5.7.2020.

>Ortego Roussel, Stephanie (2013) An analysis of femininity: how popular female characters in the media portray contemporary womanhood. LSU Master's Theses. 3089. Baton Rouge: Louisiana State University and Agricultural and Mechanical College.

$>$ Rivers, Nicola (2017) Postfeminism(s) and the Arrival of the Fourth Wave. Cheltenham:

Palgrave Macmillan.

>Ross, Karen i Byerly, Carolyn M. (2004) Women and Media: International Perspectives. Oxford:

Blackwell.

>Samuels, Curtis A. i Woodhill, Brenda M. (2004) Desirable and Undesirable Androgyny:

A Prescription for The Twenty-First Century. Journal of Gender Studies 13(1): 15-28. DOI: $10.1080 / 0958923032000184943$

>Stets, Jan E. i Burke, Peter J. (2000) Femininity/Masculinity, str. 997-1005 u: Borgatta, Edgar F. i

Montgomery, Rhonda J. V. (ur.) Encyclopaedia of Sociology. New York: Macmillan.

>Škvorc, Boris i Korljan, Josipa (2009) Upisivanje ženskosti u popularnu/fantastičnu/političku teksturu gledišta - o prozi Dubravke Ugrešić. Zbornik radova Filozofskog fakulteta u Splitu 2009/2010 (2/3): 65-84.

$>$ Vesey, Alyxandra (2015) Putting Her on the Shelf: Pop star fragrances and postfeminist entrepreneurialism. Feminist Media Studies 15 (6): 1-17. DOI: 10.1080/14680777.2015.1033639 $>$ Walter, Natasha (2011) Žive lutke. Povratak seksizma. Zagreb: Algoritam.

$>$ Walters, Margaret (2005) Feminism: A Very Short Introduction. New York: Oxford University Press.

$>$ Wolf, Naomi (2002) The Beauty Myth. New York: Harper Collins. 


\title{
THE PORTRAYAL OF A 21ST CENTURY EMANCIPATED WOMAN IN PERFUME COMMERCIALS
}

\section{Lana Gajger :: Viktorija Car}

\begin{abstract}
In the 21st century, the feminist movement is experiencing a new upswing. This process is particularly affected by the activity of female celebrities who promote and embody the idea of woman emancipation. The main goal of this paper is to identify the ways in which female perfume commercials present emancipation as desirable. By means of narrative analysis and the qualitative research method, we analysed five perfume commercials featuring female celebrities as their main protagonists. The common characteristics shared by all the protagonists in the analysed commercials is their determination and a pronounced sense of self-awareness and insurgence. They are extroverted, assertive, and prone to seeking excitement, competent and success-oriented. Their desirability is simultaneously determined by masculine behaviour, feminine aesthetics, the rejection of gender norms (with the exception of the slimness ideal), dominant behaviour when interacting with men, and the focus towards the future. The behaviour of female protagonists almost completely matches the characteristics of the postfeminist understanding of femininity and supports the fundamental determinant of feminism - the idea of emancipation.
\end{abstract}

\section{KEYWORDS}

EMANCIPATION, POSTFEMINISM, FOURTH WAVE OF FEMINISM, CELEBRITIES, PERFUME COMMERCIAL

Authors note

Lana Gajger :: University of Zagreb, Faculty of Political Science, Croatia :: lanagajger@gmail.com

Viktorija Car :: University of Zagreb, Faculty of Political Science, Croatia :: viktorija.car@fpzg.hr 